\title{
Mechanisms of Preconditioning Exercise-Induced Neurovascular Protection in Stroke
}

\author{
Sherif Hafez, ${ }^{\mathrm{a}, \mathrm{b}}$ Zeina Eid, ${ }^{\mathrm{c}}$ Sara Alabasi, ${ }^{\mathrm{c}}$ Yasenya Darwiche, ${ }^{\mathrm{c}}$ Sara Channaoui, ${ }^{\mathrm{c}}$ David C. Hess ${ }^{\mathrm{b}}$ \\ aDepartment of Pharmaceutical Sciences, College of Pharmacy Mercer University, Atlanta, GA, USA \\ ${ }^{b}$ Neurology Department, Augusta University, Augusta, GA, USA \\ 'College of Pharmacy Larkin University, Miami, FL, USA
}

Ischemic stroke is a leading cause of death and disability. Tissue plasminogen activator is the only U.S. Food and Drug Administration approved thrombolytic therapy for ischemic stroke patients till date. However, its use is limited due to increased risk of bleeding and narrow therapeutic window. Most of the preclinically tested pharmacological agents failed to be translated to the clinic. This drives the need for alternative therapeutic approaches that not only provide enhanced neuroprotection, but also reduce the risk of stroke. Physical exercise is a sort of preconditioning that provides the body with brief ischemic episodes that can protect the body from subsequent severe ischemic attacks like stroke. Physical exercise is known to improve cardiovascular health. However, its role in providing neuroprotection in stroke is not clear. Clinical observational studies showed a correlation between regular physical exercise and reduced risk and severity of ischemic stroke and better outcomes after stroke. However, the underlying mechanisms through which prestroke exercise can reduce the stroke injury and improve the outcomes are not completely understood. The purpose of this review is to: demonstrate the impact of exercise on stroke outcomes and show the potential role of exercise in stroke prevention and recovery; uncover the underlying mechanisms through which exercise reduces the neurovascular injury and improves stroke outcomes aiming to develop novel therapeutic approaches.

Keywords Stroke; Exercise therapy; Neuroprotection; Ischemic stroke

\author{
Correspondence: Sherif Hafez \\ Department of Pharmaceutical Sciences, \\ College of Pharmacy Mercer University, \\ 3001 Mercer University Dr, Atlanta, GA \\ 30341 , USA \\ Tel: +1-678-547-6241 \\ Fax: +1-678-547-6423 \\ E-mail:hafez_s@mercer.edu \\ https://orcid.org/0000-0003-4980-4467
}

Received: July 21, 2020

Revised: September 10, 2021

Accepted: September 13, 2021

\section{Introduction}

Ischemic stroke is a leading cause of death and disability. Many neuroprotective pharmacological agents have been pre-clinically tested in animal models to reduce the stroke injury, but they all failed to be translated to the clinic. To date, tissue plasminogen activator (tPA) and mechanical thrombectomy are the only two effective treatments for ischemic stroke, with IPA being the only pharmacological U.S. Food and Drug Administration approved thrombolytic therapy., With the failure of pharmacological agents that target single pathways, other ap- proaches are pursued to stimulate brain self-protection. These approaches aim to exploit multiple endogenous protective pathways triggered by preconditioning to induce neuroprotection. Preconditioning is the concept of applying small doses of a lethal insult to protect against later lethal doses. Ischemic preconditioning involves short durations of ischemia that protect against later longer and more lethal durations. Remote ischemic conditioning (RIC) uses brief alternate episodes of ischemia/reperfusion to a distant organ, like the limbs, which can in turn provide protection to the heart or the brain if subjected to prolonged ischemia later. ${ }^{3}$ Exercise is a form of pre- 
conditioning that bears similarities to ischemic preconditioning. We have recently reviewed the role of RIC in providing neuroprotection to the brain in different neurological ischemic diseases like stroke and vascular cognitive impairment. ${ }^{4}$ This review will focus on the role of exercise preconditioning in offering neuroprotection in stroke.

Exercise preconditioning provides brief ischemic episodes that can protect the body from the detrimental effects of subsequent prolonged ischemic attacks like myocardial infarction or stroke. ${ }^{5}$ Clinical observational studies showed that exercise reduces not only the risk of stroke, but also reduces the severity of the injury after stroke. However, the exact mechanism through which exercise reduces the risk and severity of stroke is not clear. Revealing and understanding the underlying mechanisms is paramount in developing novel therapeutic approaches as exercise pharmacological mimetics to enhance stroke therapy. This review will cover the findings from clinical studies about the impact of exercise on stroke risk and severity, and the different preconditioning exercise animal models employed in stroke in order to reveal the underlying mechanisms through which exercise improves stroke outcomes.

\section{Ethical approval}

This article does not contain any studies with human participants performed by any of the authors and it does not contain any animal work.

\section{Physical exercise and ischemic stroke: clinical evidence}

In the 1950s, Morris et al. ${ }^{6}$ first demonstrated the cardiovascular benefits of physical exercise in the London Transport Workers Study. Physical exercise refers to all forms of physical activity, whether it is a daily life activity or an exercise routine. Morris et al. ${ }^{7}$ found that conductors who ascended steps all day had half the rate of sudden cardiac death as the sedentary drivers of London double decker buses. Physical exercise has been shown to lower blood pressure, improve the lipids profile, aid weight loss, increase insulin sensitivity and reduce the risk of diabetes. ${ }^{8-12}$ In addition, physical exercise was shown to improve endothelial function, reduce blood viscosity, fibrinogen levels, platelet aggregability and enhance fibrinolysis. ${ }^{13-16} \mathrm{How}-$ ever, the impact of pre-stroke physical exercise on stroke risk, severity, and post-stroke outcomes is not clear.

\section{Physical exercise reduces stroke risk}

Findings from the Honolulu Heart Program showed that physical exercise reduced the risk of stroke among more than 7,000 men over 22 years follow-up study. ${ }^{17}$ The National Health and Nutrition Examination Survey 1 (NHANES 1) follow-up study showed that physical inactivity is associated with increased risk of stroke incidence in both men and women. ${ }^{18}$ In the Northern Manhattan Stroke Study, leisure time physical exercise was related to a decreased occurrence of stroke in an elderly, urban, multi-ethnic population..$^{19}$ In 2003, Lee et al. ${ }^{20}$ showed in a large meta-analysis study that higher physical exercise was associated with lower risk of stroke incidence and mortality. In 2009, Willey et al. ${ }^{21}$ showed that moderate to heavy physical exercise was associated with reduction in stroke risk in men but not in women. The Harvard Alumni Health Study also showed that physical exercise was associated with decreased stroke risk. ${ }^{22}$ However, the group showed a U-shaped relation where there was less reduction in the risk with higher levels of physical exercise. ${ }^{22}$ In a prospective study of over a million women in the United Kingdom, moderate physical exercise reduced the risk of venous thromboembolism, coronary heart disease, and cerebrovascular disease. ${ }^{23}$ However, there appeared to be a U-shaped dose response with a loss of protection against these cardiovascular events in women with more intense physical exercise. While most of the observational studies focused on the effect of long term (years) effects of physical exercise before the stroke, one study by Krarup et al. ${ }^{24}$ recruited stroke patients from hospitals covering Copenhagen City investigated the effect of physical exercise performed during the week preceding an ischemic stroke. The study showed that stroke patients were less physically active in the week before stroke than age and sex matched controls. ${ }^{24}$ As shown in this section, findings from clinical studies showed that physical exercise reduces the risk of stroke incidence (Table 1).

\section{Physical exercise reduces the severity of stroke injury and improves functional outcomes}

Clinical observational studies showed a positive correlation between pre-stroke exercise and better stroke outcomes. ${ }^{25}$ Prestroke exercise was associated with reduced stroke injury and improved functional outcomes. ${ }^{25}$ This was indicated by a significant reduction in the National Institutes of Health Stroke Scale (NIHSS) scores in the pre-stroke exercise patients groups. Data collected for patients enrolled in the Ischemic Stroke Genetics Study showed that higher levels of pre-stroke physical exercise were associated with better functional outcomes at enrollment and 3 months after stroke. ${ }^{26}$ 
Table 1. The impact of pre-stroke exercise on reducing the risk of stroke in clinical studies

\begin{tabular}{|c|c|c|c|}
\hline Study & Study population/duration & Study objectives & Stroke outcomes \\
\hline $\begin{array}{l}\text { Abbott et al. (1994) } \\
\text { Honolulu Heart Program }\end{array}$ & $\begin{array}{l}7,530 \text { men } \\
\text { Age: } 45-68 \text { years } \\
\text { Over } 22 \text { years }\end{array}$ & $\begin{array}{l}\text { Examines the relation between the levels of } \\
\text { pre-stroke exercise and stroke risk }\end{array}$ & $\begin{array}{l}\text { Physical exercise significantly reduced the risk } \\
\text { of stroke }\end{array}$ \\
\hline $\begin{array}{l}\text { Gillum et al. }(1996)^{18} \\
\text { NHANES } 1\end{array}$ & $\begin{array}{l}5,852 \text { (men \& women) } \\
\text { Age: } 45-74 \text { years } \\
\text { Average follow-up of } 11.6 \text { years }\end{array}$ & $\begin{array}{l}\text { Examine impact of exercise on stroke } \\
\text { incidence }\end{array}$ & $\begin{array}{l}\text { Physical inactivity was associated with } \\
\text { increased risk of stroke }\end{array}$ \\
\hline $\begin{array}{l}\text { Sacco et al. }(1998)^{19} \\
\text { The Northern Manhattan } \\
\text { Stroke Study }\end{array}$ & $\begin{array}{l}1,047 \text { (men } \& \text { women) } \\
\text { Age: } 69.9 \pm 12 \text { years } \\
\text { Over } 30 \text { months }\end{array}$ & $\begin{array}{l}\text { Investigate the association between leisure- } \\
\text { time physical exercise and ischemic stroke }\end{array}$ & $\begin{array}{l}\text { Leisure-time physical exercise significantly } \\
\text { reduced the occurrence of ischemic stroke }\end{array}$ \\
\hline $\begin{array}{l}\text { Willey et al. }(2009)^{21} \\
\text { The Northern } \\
\text { Manhattan Study }\end{array}$ & $\begin{array}{l}3,298 \text { (men } \& \text { women) } \\
\text { Age: } 69.2 \pm 10.3 \text { years } \\
\text { Median of } 9.1 \text { years }\end{array}$ & $\begin{array}{l}\text { Examine the effect of physical exercise, as } \\
\text { measured by intensity on protection against } \\
\text { ischemic stroke }\end{array}$ & $\begin{array}{l}\text { Moderate- to heavy-intensity physical } \\
\text { exercise is protective against risk of ischemic } \\
\text { stroke in men, but not in women }\end{array}$ \\
\hline $\begin{array}{l}\text { Lee et al. }(1998)^{22} \\
\text { The Harvard alumni } \\
\text { Health Study }\end{array}$ & $\begin{array}{l}11,130 \text { men } \\
\text { Mean age: } 58 \text { years } \\
\text { Around } 13 \text { years (from } 1977 \text { till } \\
\text { 1990) }\end{array}$ & $\begin{array}{l}\text { Examine the effect of different types of } \\
\text { exercise (walking, climbing stairs, } \\
\text { participation in sports and recreational } \\
\text { activities) on stroke risk }\end{array}$ & $\begin{array}{l}\text { Physical exercise was associated with } \\
\text { decreased stroke risk in men }\end{array}$ \\
\hline Armstrong et al. $(2015)^{23}$ & $\begin{array}{l}1.1 \text { million women } \\
\text { Age: } 50-64 \text { years } \\
\text { Around } 9 \text { years follow-up }\end{array}$ & $\begin{array}{l}\text { Examine the effects of the frequency and } \\
\text { duration of exercise on the incidence of } \\
\text { coronary heart disease, venous } \\
\text { thromboembolism and cerebrovascular } \\
\text { diseases }\end{array}$ & $\begin{array}{l}\text { Physical exercise was associated with a lower } \\
\text { risk of coronary heart disease, venous } \\
\text { thromboembolic event, and cerebrovascular } \\
\text { disease than inactivity }\end{array}$ \\
\hline Krarup et al. $(2007)^{24}$ & $\begin{array}{l}428 \text { (men \& women) } \\
\text { Age } \geq 40 \text { years } \\
2003-2004\end{array}$ & $\begin{array}{l}\text { Investigate the level of physical exercise of } \\
\text { stroke patient during the week preceding } \\
\text { the stroke event }\end{array}$ & $\begin{array}{l}\text { Stroke patients are less physically active in } \\
\text { the week preceding an ischemic stroke when } \\
\text { compared to age- and sex-matched controls }\end{array}$ \\
\hline
\end{tabular}

Table 1 summarizes the clinical studies that showed a positive impact of exercise on reducing the risk of stroke. NHANES 1, National Health and Nutrition Examination Survey 1.

A recent systematic study in 2021 showed that pre-stroke physical exercise may be associated with reduction in admission stroke severity. ${ }^{27}$ The study showed that pre-stroke exercise was associated with reduction in infarct size, reduced risk factors for stroke and distal occlusion. ${ }^{27}$ In 2020, Damsbo et al. ${ }^{28}$ showed that pre-stroke exercise was associated with better cognitive performance at 1 and 6 months after stroke. In 2018, Reinholdsson et al. ${ }^{29}$ showed that light exercise like walking 4 hours/week or moderate exercise of 2 to 3 hours/ week, both were associated with less severe stroke and better functional outcomes as indicated by lower NIHSS scores. On the other side, physical inactivity was associated with increased stroke severity. ${ }^{29}$ Deplanque et al. ${ }^{30,31}$ showed that leisure-time exercise was associated with less stroke severity, better short-term stroke outcomes, reduction in neurological deficits and improvement in functional outcomes. In 2015, Ursin et al. ${ }^{32}$ also showed that pre-stroke exercise demonstrated significant association with improved functional outcomes after stroke. In 2017, Wen et al. ${ }^{33}$ showed that prestroke exercise for at least 30 minutes a day, three times a week, was associated with reduced stroke injury, lower mortality rate and better functional outcomes. In a sub study of the ExStroke Pilot trial in Denmark, physical exercise prior to stroke was associated with less severe stroke and better longterm outcome. ${ }^{34}$ An interesting study published in 2017 showed that the level of physical exercise the week before the incidence of stroke correlated significantly to a reduction in the 24-hour cerebral infarct size in stroke patients treated with remote ischemic perconditioning (RIPerC) in addition to IV tPA. ${ }^{35}$ In 2014, Ricciardi et al. ${ }^{36}$ also showed that pre-stroke exercise was associated with better functional outcomes, less stroke severity at admission, early arterial recanalization, and smaller final infarct size. An interesting study in 2017 showed that pre-stroke exercise was associated with an increase in serum level of vascular endothelial growth factor (VEGF). This increase in VEGF levels correlated to improvement in functional outcomes and reduction in infarct size compared to physically inactive patients. ${ }^{37} \mathrm{~A}$ prospective study, that was part of the Women's Health Initiative in the United States, showed that pre-stroke physical activity was associated with lower post-stroke mortality in older women. ${ }^{38}$ In conclusion, findings from the above-mentioned clinical studies showed that pre-stroke physical exercise was associated with lower stroke severity, smaller infarcts and better functional outcomes (Table 2). 
Table 2. The impact of pre-stroke exercise on stroke severity in clinical studies

\begin{tabular}{|c|c|c|c|}
\hline Study & Study population/duration & Study objectives & Stroke outcomes \\
\hline Stroud et al. (2009) $)^{26}$ & $\begin{array}{l}673 \text { (men \& women) } \\
\text { Age: } 50-80 \text { years } \\
\text { 2002-2007 }\end{array}$ & $\begin{array}{l}\text { Examine the effect of pre-stroke exercise on } \\
\text { stroke severity and outcomes }\end{array}$ & $\begin{array}{l}\text { Higher levels of pre-stroke exercise was } \\
\text { associated with improved stroke outcomes }\end{array}$ \\
\hline Reinholdsson et al. $(2018)^{29}$ & $\begin{array}{l}925 \text { (men \& women). } \\
\text { Mean age: } 73.1 \text { years } \\
\text { 2014-2016 }\end{array}$ & $\begin{array}{l}\text { Examine the effect of pre-stroke exercise on } \\
\text { acute stroke severity }\end{array}$ & $\begin{array}{l}\text { Pre-stroke exercise was associated with less } \\
\text { severe stroke and improved functional outcomes }\end{array}$ \\
\hline Deplanque et al. $(2006)^{30}$ & $\begin{array}{l}362 \text { (men } \& \text { women) } \\
\text { Median age: } 70 \text { years } \\
\text { 2002-2004 }\end{array}$ & $\begin{array}{l}\text { Determine the factors that can affect initial } \\
\text { severity of stroke and short-term outcomes }\end{array}$ & $\begin{array}{l}\text { Pre-stroke exercise was associated with reduced } \\
\text { severity and improved functional outcomes }\end{array}$ \\
\hline Wen et al. $(2017)^{33}$ & $\begin{array}{l}39,835 \text { (men } \& \text { women) } \\
\text { Age: } 20 \text { to } \geq 65 \text { years } \\
2006-2009\end{array}$ & $\begin{array}{l}\text { Examine the effect of pre-stroke exercise on } \\
\text { stroke outcomes }\end{array}$ & $\begin{array}{l}\text { Leisure-time exercise for at least } 30 \mathrm{~min} / \text { day, } 3 \\
\text { times/week for more than } 6 \text { months was } \\
\text { associated with reduced stroke severity, better } \\
\text { functional outcomes \& lower mortality }\end{array}$ \\
\hline Krarup et al. (2008) $)^{34}$ & $\begin{array}{l}265 \text { (men } \& \text { women) } \\
\text { Mean age: } 68 \pm 12.2 \text { years } \\
\text { Duration: } 2 \text { years }\end{array}$ & $\begin{array}{l}\text { Examine whether pre-stroke physical exercise } \\
\text { influences severity of stroke injury and long- } \\
\text { term outcome }\end{array}$ & $\begin{array}{l}\text { Pre-stroke exercise reduced: } \\
\text { Severity of stroke injury } \\
\text { Improved the long-term outcomes }\end{array}$ \\
\hline Blauenfeldt et al. $(2017)^{35}$ & $\begin{array}{l}102 \text { (men } \& \text { women) } \\
\text { Age: } 58-74 \text { years } \\
\text { 2009-2011 }\end{array}$ & $\begin{array}{l}\text { Examine the effect of pre-stroke exercise on } \\
\text { cerebral infarcts in stroke patients treated with } \\
\text { IV tPA and RIPerC }\end{array}$ & $\begin{array}{l}\text { Pre-stroke exercise the week before stroke was } \\
\text { associated with decreased infarct size in stroke } \\
\text { patients treated with RIPerC and IV tPA }\end{array}$ \\
\hline Ricciardi et al. (2014) ${ }^{36}$ & $\begin{array}{l}159 \text { (men \& women) } \\
\text { Mean age: } 68 \text { years } \\
\text { 2008-2011 }\end{array}$ & $\begin{array}{l}\text { Examine the impact of pre-stroke exercise on } \\
\text { stroke outcome }\end{array}$ & $\begin{array}{l}\text { Pre-stroke exercise: } \\
\text { Improved functional outcomes } \\
\text { Improved recanalization } \\
\text { Reduced infarct size }\end{array}$ \\
\hline Lopez et al. $(2017)^{37}$ & $\begin{array}{l}83 \text { (men \& women) } \\
\text { Mean age: } 69.6 \text { years } \\
\text { 2008-2011 }\end{array}$ & $\begin{array}{l}\text { Examine effect of pre-stroke exercise on stroke } \\
\text { outcomes } \\
\text { Investigate molecular mechanisms }\end{array}$ & $\begin{array}{l}\text { Pre-stroke PA: } \\
\text { Increased VEGF serum level } \\
\text { Reduced infarct size, and } \\
\text { Improved functional outcomes }\end{array}$ \\
\hline Bell et al. $(2013)^{38}$ & $\begin{array}{l}\text { 3,173 women } \\
\text { Age: } 50-79 \text { years } \\
1993-2010\end{array}$ & $\begin{array}{l}\text { Examine pre-stroke lifestyle factors associated } \\
\text { with post stroke mortality in older women }\end{array}$ & $\begin{array}{l}\text { Pre-stroke exercise was associated with lower } \\
\text { mortality after stroke }\end{array}$ \\
\hline
\end{tabular}

Table 2 summarizes the clinical studies that showed a positive impact of exercise on reducing the severity of stroke injury.

IV, intravenous; RIPerC, remote ischemic perconditioning; tPA, tissue plasminogen activator; PA, plasminogen activator; VEGF, vascular endothelial growth factor.

\section{Preconditioning exercise and ischemic stroke: preclinical evidence}

In this section, we are going to cover: (1) The different preconditioning exercise animal models employed in stroke; (2) The impact of preconditioning exercise on stroke outcomes; (3) The underlying mechanisms through which preconditioning exercise reduces the neurovascular injury and improve stroke outcomes.

\section{Preconditioning exercise experimental models and impact on stroke outcomes}

Preconditioning exercise refers to providing pre-stroke exercise in animal models as sort of conditioning to improve stroke outcomes. Preclinical studies showed that preconditioning exercise reduced the neurovascular injury and improved stroke outcomes (Table 3).
Tahamtan et al. ${ }^{39}$ showed that rats subjected to treadmill running for 3 weeks prior to stroke showed better outcomes than non-exercised rats. Preconditioning exercise reduced neuronal injury and this was associated with improved novel object recognition, beam walk, and adhesive removal scores. ${ }^{39}$ Shamsaei et al. ${ }^{40}$ showed that subjecting rats to pre-stroke treadmill running for 4 weeks had significantly reduced brain edema and neurological deficits after stroke. Chen et al. ${ }^{41}$ showed that forced non-electric shock running wheel (FNESRW) training for 3 weeks before stroke led to enhancement of motor and neurological functions and significant reduction in infarct volumes. However, the FNESRW-induced improvement was similar to that seen with treadmill training. ${ }^{41}$

Although it was shown that preconditioning exercise can induce post-stroke neurovascular protection, the mechanisms through which exercise offers this protection is still not completely clear. It is likely a combination of multiple and highly interacting pathways rather than just a single mechanism. In 
Table 3. The impact of preconditioning exercise on stroke outcomes in preclinical studies

\begin{tabular}{|c|c|c|c|}
\hline Study & Exercise model & Stroke model & Stroke outcome \\
\hline Tahamtan et al. $(2013)^{39}$ & $\begin{array}{l}\text { Rats, treadmill running, } 30 \text { minutes a day, } \\
5 \text { days a week for } 3 \text { weeks }\end{array}$ & Four-vessel occlusion method & $\begin{array}{l}\uparrow \text { Recognition memory } \\
\uparrow \text { Sensorimotor functions } \\
\uparrow \text { Behavioral outcomes } \\
\downarrow \text { Neuronal injury }\end{array}$ \\
\hline Shamsaei et al. $(2017)^{40}$ & $\begin{array}{l}\text { Rats, treadmill running, ascending order } \\
(15-45 \text { minutes a day), } 5 \text { days a week for } \\
4 \text { weeks }\end{array}$ & tMCAO for 60 minutes (suture occlusion) & $\begin{array}{l}\downarrow \text { Brain edema } \\
\downarrow \text { Neurological disorders }\end{array}$ \\
\hline Chen et al. $(2014)^{41}$ & $\begin{array}{l}\text { Rats, FNESRW } \\
\text { Rats, treadmill for } 1 \text { hour a day, } 3 \text { days a } \\
\text { week for } 3 \text { weeks }\end{array}$ & tMCAO for 60 minutes (suture occlusion) & $\begin{array}{l}\uparrow \text { Muscles' strength } \\
\uparrow \text { Motor function } \\
\uparrow \text { Neurological outcomes } \\
\downarrow \text { Infarct volume }\end{array}$ \\
\hline Zwagerman et al. (2010) $)^{44}$ & $\begin{array}{l}\text { Rats, treadmill running, } 30 \text { minutes a day, } \\
5 \text { days a week for } 3 \text { weeks }\end{array}$ & tMCAO for 2 hours (suture occlusion) & $\begin{array}{l}\uparrow \text { Cerebral blood flow during reperfusion } \\
\downarrow \text { Brain infarct }\end{array}$ \\
\hline Guo et al. $(2008)^{46}$ & $\begin{array}{l}\text { Rats, treadmill running, } 30 \text { minutes a day, } \\
5 \text { days a week, for } 3 \text { weeks }\end{array}$ & tMCAO for 2 hours (suture occlusion) & $\begin{array}{l}\uparrow B B B \text { function } \\
\uparrow B \text { Basal lamina integrity }\end{array}$ \\
\hline Chaudhry et al. (2010) ${ }^{47}$ & $\begin{array}{l}\text { Rats, treadmill running, } 30 \text { minutes a day, } \\
5 \text { days a week for } 3 \text { weeks }\end{array}$ & tMCAO for 120 minutes (suture occlusion) & $\begin{array}{l}\downarrow \text { Infarct volume } \\
\downarrow \text { Neuronal apoptosis }\end{array}$ \\
\hline Curry et al. $(2010)^{49}$ & $\begin{array}{l}\text { Rats, treadmill running, } 30 \text { minutes a day, } \\
5 \text { days a week, for } 3 \text { weeks }\end{array}$ & tMCAO for 2 hours (suture occlusion) & $\begin{array}{l}\downarrow \text { Infarct volume } \\
\downarrow \text { Brain inflammation }\end{array}$ \\
\hline Ding et al. $(2006)^{51}$ & $\begin{array}{l}\text { Rats, treadmill running, } 30 \text { minutes a day, } \\
6 \text { days a week for } 3 \text { weeks }\end{array}$ & tMCAO for 2 hours (suture occlusion) & $\begin{array}{l}\downarrow \text { Infarct volume } \\
\uparrow \text { Neurovascular integrity } \\
\downarrow \text { Brain edema }\end{array}$ \\
\hline Li et al. $(2004)^{52}$ & $\begin{array}{l}\text { Rats, treadmill running, } 30 \text { minutes a day, } \\
6 \text { days a week for } 3 \text { weeks }\end{array}$ & tMCAO for 2 hours (suture occlusion) & $\begin{array}{l}\uparrow \text { Neuroprotection } \\
\downarrow \text { Neurologic deficit } \\
\downarrow \text { Infarct volume }\end{array}$ \\
\hline Naderi et al. (2018) ${ }^{53}$ & $\begin{array}{l}\text { Mice, treadmill running } 40 \text { mins a day, } \\
5 \text { days a week, for } 4 \text { weeks }\end{array}$ & pMCAO (MCA thermocoagulation) & $\begin{array}{l}\downarrow \text { Infarct size } \\
\uparrow \text { Neurological and functional outcomes }\end{array}$ \\
\hline Ding et al. $(2004)^{56}$ & $\begin{array}{l}\text { Rats, treadmill running, } 30 \text { minutes a day, } \\
6 \text { days a week, for either } 1,3 \text {, or } 6 \text { weeks }\end{array}$ & tMCAO for 2 hours (suture occlusion) & $\begin{array}{l}\downarrow \text { Brain injury } \\
\uparrow \text { Angiogenesis }\end{array}$ \\
\hline Ding et al. $(2004)^{59}$ & $\begin{array}{l}\text { Rats, treadmill running, } 30 \text { minutes a day, } \\
6 \text { days a week for } 3 \text { weeks }\end{array}$ & tMCAO for 2 hours (suture occlusion) & $\begin{array}{l}\uparrow \text { Neuroprotection } \\
\downarrow \text { Neurologic deficit } \\
\downarrow \text { Infarct volume }\end{array}$ \\
\hline Ding YH et al. $(2006)^{60}$ & $\begin{array}{l}\text { Rats, treadmill running } 30 \text { minutes a day } \\
\text { for } 3 \text { weeks }\end{array}$ & tMCAO for 2 hours (suture occlusion) & $\begin{array}{l}\downarrow \text { Brain infarct } \\
\downarrow \text { Brain edema } \\
\uparrow \text { Basal lamina thickness }\end{array}$ \\
\hline Otsuka et al. (2016) ${ }^{61}$ & $\begin{array}{l}\text { Rats, treadmill running, } 30 \text { minutes a day, } \\
5 \text { days a week, for } 3 \text { weeks }\end{array}$ & tMCAO for 60 minutes (suture occlusion) & $\begin{array}{l}\downarrow \text { Neurological deficits } \\
\downarrow \text { Infarct volume } \\
\downarrow \text { Neuronal apoptosis }\end{array}$ \\
\hline Endres et al. $(2003)^{62}$ & $\begin{array}{l}\text { Mice, treadmill running, } 30 \text { minutes a day, } \\
5 \text { days a week, for } 3 \text { weeks }\end{array}$ & tMCAO for 60 minutes (suture occlusion) & $\begin{array}{l}\downarrow \text { Brain infarct } \\
\uparrow \text { Cerebral blood flow } \\
\uparrow \text { Neurological outcomes }\end{array}$ \\
\hline Hafez et al. (2019) ${ }^{64}$ & $\begin{array}{l}\text { Rats, treadmill running, HIIT, } 5 \text { times } \\
\text { before stroke }\end{array}$ & Thromboembolic stroke & $\begin{array}{l}\downarrow \text { Brain infarct } \\
\uparrow \text { Cerebral blood flow } \\
\uparrow \text { Neurological outcomes }\end{array}$ \\
\hline Zhang et al. (2014) ${ }^{65}$ & $\begin{array}{l}\text { Rats, treadmill running, } 30 \text { minutes a day, } \\
5 \text { days a week for } 2 \text { weeks }\end{array}$ & tMCAO for 120 minutes (suture occlusion) & $\begin{array}{l}\uparrow \text { Cerebral blood flow } \\
\downarrow \text { Infarct volume } \\
\uparrow \text { Neuroprotection and faster recovery }\end{array}$ \\
\hline Zhang et al. (2010) ${ }^{69}$ & $\begin{array}{l}\text { Rats, treadmill running, } 30 \text { minutes a day, } \\
6 \text { days a week for } 3 \text { weeks }\end{array}$ & tMCA0 for 120 minutes (suture occlusion) & $\downarrow$ Infarct volume \\
\hline Yang et al. $(2012)^{70}$ & $\begin{array}{l}\text { Rats, treadmill running, } 30 \text { minutes a day, } \\
5 \text { days a week for } 3 \text { weeks }\end{array}$ & tMCAO for 120 minutes (suture occlusion) & $\begin{array}{l}\uparrow \text { Neurological outcomes } \\
\downarrow \text { Infarct volume }\end{array}$ \\
\hline Wang et al. (2014) ${ }^{71}$ & $\begin{array}{l}\text { Rats, treadmill running, } 30 \text { minutes a day, } \\
6 \text { days a week for } 3 \text { weeks }\end{array}$ & tMCAO for 2 hours (suture occlusion) & $\begin{array}{l}\downarrow \text { Brain infarct volume } \\
\downarrow \text { Cerebral edema } \\
\downarrow \text { Neurological deficits }\end{array}$ \\
\hline
\end{tabular}


Table 3. Continued

\begin{tabular}{|c|c|c|c|}
\hline Study & Exercise model & Stroke model & Stroke outcome \\
\hline Zhang et al. (2010) $)^{72}$ & $\begin{array}{l}\text { Rats, treadmill running, } 30 \text { minutes a day, } \\
6 \text { days a week for } 4 \text { weeks }\end{array}$ & tMCA0 for 120 minutes (suture occlusion) & $\downarrow$ Infarct volume \\
\hline Shamsaei et al. $(2015)^{73}$ & $\begin{array}{l}\text { Rats, treadmill running, } 10-15 \text { minutes a } \\
\text { day, } 5 \text { days a week for } 4 \text { weeks }\end{array}$ & $\begin{array}{l}\text { CCAs occlusion by aneurism microclips for } \\
20 \text { minutes }\end{array}$ & $\begin{array}{l}\downarrow \text { Necrotic cell death of hippocampal } \\
\text { neurons } \\
\downarrow \text { TUNEL-positive cells } \\
\downarrow \text { Apoptotic cell death }\end{array}$ \\
\hline Aboutaleb et al. (2015) & $\begin{array}{l}\text { Rats, treadmill running, } 35 \text { minutes a day, } \\
5 \text { days a week for } 4 \text { weeks }\end{array}$ & $\begin{array}{l}\text { CCAs occlusion by aneurism microclips for } \\
20 \text { minutes }\end{array}$ & $\begin{array}{l}\downarrow \text { Apoptotic cell death } \\
\downarrow \text { Neuronal death }\end{array}$ \\
\hline Terashi et al. (2019) ${ }^{75}$ & $\begin{array}{l}\text { Rats, treadmill running for } 30 \text { minutes a } \\
\text { day, } 3 \text { to } 5 \text { days a week for } 3 \text { weeks }\end{array}$ & tMCAO for 60 minutes (suture occlusion) & $\begin{array}{l}\downarrow \text { Infarct volumes } \\
\uparrow \text { Neurological scores } \\
\uparrow \text { Sensorimotor function }\end{array}$ \\
\hline Otsuka et al. $(2018)^{76}$ & $\begin{array}{l}\text { Rats, treadmill running, } 30 \text { minutes a day, } \\
5 \text { days a week for } 3 \text { weeks }\end{array}$ & tMCAO for 60 minutes (suture occlusion) & $\begin{array}{l}\downarrow \text { Infarct size } \\
\downarrow \text { Neurological deficits }\end{array}$ \\
\hline Wang et al. $(2015)^{81}$ & $\begin{array}{l}\text { Rats were made to swim } 60 \text { minutes a } \\
\text { day, } 6 \text { days a week for } 4 \text { weeks }\end{array}$ & tMCAO for 120 minutes (suture occlusion) & $\downarrow$ Cerebral infarcts \\
\hline Liebelt et al. $(2010)^{85}$ & $\begin{array}{l}\text { Rats, treadmill running, } 30 \text { minutes a day, } \\
5 \text { days a week for either } 1,2 \text {, or } 3 \text { weeks }\end{array}$ & tMCAO for 2 hours (suture occlusion) & $\begin{array}{l}\downarrow \text { Neuronal apoptosis } \\
\downarrow \text { Brain infarct }\end{array}$ \\
\hline Wang et al. (2019) ${ }^{86}$ & $\begin{array}{l}\text { Rats, treadmill running, } 30 \text { to } 60 \text { minutes } \\
\text { a day, } 5 \text { days a week for } 3 \text { weeks }\end{array}$ & tMCAO for 60 minutes (suture occlusion) & $\begin{array}{l}\downarrow \text { Infarct size } \\
\downarrow \text { Brain edema } \\
\downarrow \text { BBB disruption } \\
\downarrow \text { Neurological motor deficits }\end{array}$ \\
\hline Wang X et al. $(2015)^{87}$ & $\begin{array}{l}\text { Rats, treadmill running for } 30 \text { mins a day, } \\
6 \text { days a week for } 3 \text { weeks }\end{array}$ & tMCAO for 90 minutes (suture occlusion) & $\begin{array}{l}\downarrow \text { Infract size } \\
\downarrow \text { Neurological deficits }\end{array}$ \\
\hline Feng et al. (2014) ${ }^{88}$ & $\begin{array}{l}\text { Rats, treadmill running } 30 \text { minutes a day, } \\
6 \text { days a week, for } 3 \text { weeks }\end{array}$ & tMCAO for 1.5 hours (suture occlusion) & $\begin{array}{l}\downarrow \text { Brain infarct volume } \\
\uparrow \text { Neurological outcomes } \\
\uparrow B B B \text { function } \\
\uparrow B \text { Basal lamina integrity }\end{array}$ \\
\hline
\end{tabular}

Table 3 summarizes the preclinical studies and animal models that showed a positive impact of preconditioning exercise on reducing stroke injury and improving outcomes.

tMCAO, transient middle cerebral artery occlusion; FNESRW, forced non-electric shock running wheel; $\mathrm{BBB}$, blood brain barrier; pMCAO, permanent middle cerebral artery occlusion; MCA, middle cerebral artery; HIIT, high intensity interval training; CCA, common carotid artery.

this section, we are going to investigate the underlying mechanisms through which preconditioning exercise reduces the neurovascular injury and improves outcomes in stroke.

\section{Mechanisms of exercise-induced neurovascular protection in stroke}

\section{Immunomodulation, matrix metalloproteases, and blood-brain barrier}

Upregulation of inflammatory cytokines and increased activity of matrix metalloproteases (MMPs) during the acute phase after stroke exacerbates the stroke injury. ${ }^{42,43}$ Preconditioning exercise was found to reduce the neurovascular injury and blood-brain barrier (BBB) disruption after stroke through modulating the immune response and MMPs activity. ${ }^{44-53}$ In 2010, Zwagerman et al. ${ }^{44}$ showed that pre-stroke exercise reduced Toll-like receptor-4 (TLR-4) expression within the brain after stroke and this correlated to reduced infarct size. In
2016, Zhu et al. ${ }^{45}$ showed that exercise preconditioning for 3 weeks prior to ischemia/reperfusion injury has significantly reduced brain infarction and neurological deficits. This was associated with a reduction in the expression of TLR-4 and nuclear factor kappa B (NF-KB) in the ischemic brain, and reduction in the concentrations of tumor necrosis factor alpha (TNFa) and interleukin-1 $\beta$ (IL-1 $\beta$ ) in the peripheral serum in exercised group. ${ }^{45}$ Studies by Guo et al. ${ }^{46}$ and Chaudhry et al. ${ }^{47}$ showed that preconditioning exercise for 3 weeks prior to middle cerebral artery occlusion (MCAO) has led to reduction in post-stroke expression of MMP9. This was associated with reduction in BBB disruption after stroke, reduced neuronal apoptosis, and increased microvascular integrity. ${ }^{46,47}$ The same group also showed that preconditioning exercise increased the pre-stroke induction of TNFa. This led to a reduction in poststroke MMP9 expression which was associated with reduction in BBB disruption and improved stroke outcomes. ${ }^{48}$ However, these findings were controversial and contradicted with the 
prevailing dogma that TNFa is deleterious and worsens stroke outcomes, especially during the acute phase of stroke injury. Moreover, TNFa leads to activation rather than downregulation of MMP9. However, the group interpreted this contradiction by estimating the beneficial role TNFa can play if upregulated before rather than after the ischemic insult. ${ }^{49}$ The group supported this interpretation by their earlier findings in 2005. They showed that pre-stroke exercise inhibits post-stroke inflammation by decreasing expression of inflammatory mediators and reducing leukocytes infiltration leading to reduced brain damage. They also showed that exercise-induced increase in the expression of TNFa before stroke may prevent the downstream inflammatory events that may regularly occur if TNFa is acutely elevated after stroke. ${ }^{50}$ This was further supported by the same group in 2006. Using the same exercise model, they showed that the preconditioning exercise-induced increase in TNFa led to reduction in expression of TNFa receptors in the brain after stroke, and this was associated with reduction in infarct size. To further support their findings, the group simulated the in vivo study in human umbilical vein endothelial cells (HUVEC). They showed that HUVEC cells pretreated with TNFa demonstrated reduced cellular expression of TNFa receptors when subjected hypoxia/reoxygenation conditions. ${ }^{51}$

In 2004, Li et al..$^{52}$ showed that pre-stroke treadmill exercise for 3 weeks reduced infarct size in models of transient MCAO but not in models of permanent stroke. Nevertheless, a recent study in 2018 by Naderi et al..$^{53}$ showed that preconditioning exercise can still induce neuroprotection in a permanent MCAO mouse model. However, the group used a completely different animal model. They investigated the impact of preconditioning exercise in ovariectomized female mice with or without administration of $17 \beta$-estradiol. They found that exercise alone or in combination with estradiol significantly reduced infarct size and improved neurological outcomes. This was associated with reduction in serum concentration of MMP9 and increase in IL-10.53

\section{Cerebral integrins, aquaporin, and brain edema}

In 2006, Ding et al. ${ }^{54}$ showed that 3 weeks of treadmill preconditioning training upregulated the expression of cerebral integrins which led to an increase in the neurovascular integrity. This led to reduction in brain injury demonstrated by reduction in brain infarction and edema after stroke. ${ }^{54}$ He et al. ${ }^{55}$ showed that preconditioning treadmill training for 2 weeks led to a significant reduction in cerebral expression of aquaporin 4 . This was associated with reduced cerebral edema and BBB leakage after stroke..$^{55}$

\section{VEGF, angiopoietin, and cerebral angiogenesis}

In 2004, Ding et al. ${ }^{56}$ conducted a study to examine whether exercise can induce the expression of VEGF and angiopoietin, and whether they correlate to good outcomes after stroke. They found that pre-stroke treadmill exercise significantly increased the expression of mRNA of VEGF, angiopoietin and increased microvascular density. The improved angiogenesis was associated with reduced infarct size and improved neurological outcome after stroke. ${ }^{56}$ In a comparison of two different running exercise models, Rezaei et al. ${ }^{57}$ showed that pre-stroke high intensity interval training (HIIT) produced better outcomes than moderate intensity continuous training. HIIT induced smaller cerebral infarction and better neurological outcomes. This was associated with higher levels of VEGF-A and VEGF-R2 in the brains of animals subjected HIIT. ${ }^{57}$ In 2014, Gao et al. ${ }^{58}$ showed that pre-stroke treadmill exercise induced better neurological recovery and smaller infarcts after stroke. This was associated with significant increase in caveolin-1 and VEGF expression. Moreover, this group showed that the administration of daidzen (caveolin-1 inhibitor) to the exercised rats increased the infarct size, worsened the neurological recovery, and reduced VEGF expression. Obviously, caveolin-1 inhibition abolished the exercise-induced benefits. Consequently, they concluded that caveolin-1 pathway is involved in the regulation of VEGF induced angiogenesis in the ischemic penumbra of rat brains after treadmill exercise. ${ }^{58}$

\section{Brain-derived neurotrophic factor}

In 2004, Ding et al. ${ }^{59}$ showed that treadmill exercising for 3 weeks before stroke significantly reduced brain infarcts and neurological deficits after stroke through increased expression of nerve growth factor (NGF), brain derived neurotrophic factor (BDNF) and increased microvascular density. Later in 2006, the same group using the same exercise model showed that preconditioning exercise significantly improved the brain's cerebrovascular integrity by reducing brain edema and reducing the ischemia-induced ultrastructural alteration in endothelialmatrix-astrocyte interfaces after stroke compared to non-exercised rats. ${ }^{60}$ Otsuka et al. ${ }^{61}$ showed that preconditioning treadmill running for 3 weeks before stroke significantly reduced the infarct size, neurological deficits, and improved motor functions. This was associated with an increased expression of midkine and BDNF, increased astrocytes proliferation and increased angiogenesis in the brain.

Endothelial nitric oxide synthase, nitric oxide, and cerebral blood flow

Endothelial nitric oxide synthase (eNOS) is a vascular endothe- 
lial enzyme that upon activation leads to the production of nitric oxide (NO). NO is a potent vasodilator and platelet aggregation inhibitor. Exercise is believed to promote neuroprotective effects at least in part through eNOS activation.

In 2003, Endres et al. ${ }^{62}$ showed that mice subjected to either voluntary running for 21 days or treadmill running for 3 weeks prior to stroke experienced better outcomes compared to nonexercised mice. They found that preconditioning exercise increased eNOS activation, NO production, and cerebral blood flow (CBF). This was associated with reduction in infarct size and improvement in neurological scores. ${ }^{62}$ In 2006, Gertz et al. ${ }^{63}$ showed also that 3 weeks of voluntary running prior to stroke increased eNOS activity and this was associated with elevated cerebral neovascularization and enhanced post-stroke long-term recovery and outcomes. By the end of 2019, an interesting study by Hafez et al. ${ }^{64}$ showed that short-term exercise can induce eNOS activation and improve stroke outcomes. Hafez et al. ${ }^{64}$ showed that short-term acute bouts of HIIT for less than 1 week have increased eNOS activation in the brain and cerebral vasculature in rats subjected to thromboembolic stroke. This was associated with reduction in brain infarction, brain edema and improvement in functional outcomes. The group showed that acute bouts of HIIT offer immediate neuroprotection that can last for up to 72 hours after the last exercise session. ${ }^{64}$

\section{Endothelin and cerebral blood flow}

Endothelin-1 is a potent vasoconstrictor. In 2014, Zhang et al..$^{65}$ showed that preconditioning treadmill training significantly reduced post-stroke endothelin-1 expression and increased $\mathrm{CBF}$ and this was associated with improvements in stroke outcomes.

\section{Glutamate and excitotoxicity}

Glutamate is an excitatory neurotransmitter and its elevation during the acute phase after stroke is one of main causes of induced neurotoxicity, neuronal injury, and infarction. ${ }^{66,67}$ In 2009, Jia et al. ${ }^{68}$ showed that treadmill training for at least 2 weeks before stroke has significantly reduced glutamate release and increased the release of gamma aminobutyric acid (GABA) in the brain during the acute phase of cerebral ischemia-reperfusion. However, the group did not study the effect of these changes on outcomes. Consequently, In 2010, Zhang et al. ${ }^{69}$ showed that preconditioning exercise-induced reduction in glutamate release has significantly reduced brain infarction and neurological deficits after stroke.

In 2012, Yang et al..$^{70}$ showed that rats stroked after being subjected to treadmill training for 2 weeks demonstrated an increase in the expression of glutamate transporter 1 (GLT-1) in brain tissue, which caused a reduction in extracellular glutamate concentration. This was associated with reduction in infarct size and improvement in neurobehavioral outcomes. ${ }^{70}$ Furthermore, Wang et al. ${ }^{71}$ showed in 2014 that pre-ischemic treadmill training exercise reduced brain infarct volume, edema and neurological deficits through upregulating the expression of protein kinase C-a, GLT-1, Akt, and phosphatidylinositol 3 kinase in the brain after ischemic stroke. Moreover, preconditioning exercise also reduced the expression of glutamate receptors like metabotropic glutamate receptor 5 and $\mathrm{N}$-methyl$\mathrm{D}$-aspartate receptor subunit type $2 \mathrm{~B}$ after stroke and this was associated with better stroke outcomes. ${ }^{72}$

\section{Caspase activity and neuronal apoptosis}

Increased caspase activity after stroke is one of the mechanisms that lead to neuronal apoptosis. Shamsaei et al. ${ }^{73}$ and Aboutaleb et al. ${ }^{74}$ showed that preconditioning exercise for 4 weeks prior to stroke significantly reduced neuronal cell death and prevented the ischemia-induced memory dysfunction by reducing $\mathrm{Bax} / \mathrm{Bcl} 2$ ratio and caspase activity in the brain. In 2019, Terashi et al..$^{75}$ investigated the impact of exercise frequency on neuroprotection after stroke. Rats were subjected to treadmill training for either one, three, or five times a week for 3 weeks before stroke. The group found that the three and five times/week groups, but not the once-a-week group, showed significant reduction in infarct size and improvement in neurological outcomes. This was associated with reduction in the expression of caspase- 3 and neuronal apoptosis. These findings concluded that at least three times of pre-stroke exercise sessions per week are required to exert post-stroke neuroprotective effects. ${ }^{75}$ Otsuka et al. ${ }^{61,76}$ showed that preconditioning exercise for 3 weeks prior to stroke caused a reduction in the expression of Bax, caspase 3, and nitrotyrosine. This was associated with reduced neuronal apoptosis.

\section{HIF-1 alpha and cerebral metabolism}

Hypoxia-inducible factors (HIFs) are transcription factors that respond to changes in oxygen availability in the cellular environment. HIF-1a regulates the transcription of many downstream genes that regulate cellular adaptation to hypoxia like glucose transporters (GLUTs), glycolytic enzymes, and VEGF. ${ }^{77,78}$ One of the potential mechanisms offered by preconditioning exercise is elevating HIF-1a levels after stroke to rescue the tissue from oxygen deprivation.

In 2018, Otsuka et al. ${ }^{76}$ showed that pre-stroke exercise for 3 weeks significantly increased the expression of HIF-1a and 14$3-3 \gamma$ (ischemia-inducible protective factor) in neurons and as- 
trocytes. This was associated with a significant reduction in brain infarction and neuronal death after stroke. ${ }^{76}$ In 2013, Dornbos et al. ${ }^{79}$ showed that preconditioning exercise reduced brain damage after stroke by ameliorating metabolic disorders. Rats subjected to stroke after 3 weeks of preconditioning exercise showed significant increase in HIF-1 $\mathrm{a}$ and adenosine monophosphate activated kinase (AMPK) levels during the acute phase after stroke which indicated reduction in metabolic disorder. GLUT1, GLUT3, and phosphofructokinase (PFK) were also increased in exercised rats showing an enhanced glycolysis and increased adenosine triphosphate production. ${ }^{79,80}$ In 2015, Wang et al. ${ }^{81}$ also showed that exercise preconditioning reduced the infarct volume through upregulation of HIF-1a expression.

In 2008, Hayes et al. ${ }^{82}$ conducted a study to investigate the differential effects of forced versus voluntary preconditioning exercise-induced neuroprotection after stroke. Forced exercise was demonstrated by treadmill running at speed of $30 \mathrm{~m} / \mathrm{min}$, 30 minutes a day, 5 days/week, for 3 weeks. The treadmill was composed of channels with an electric shock grid built into each channel, which can stimulate the rats to run. Voluntary exercise was achieved by housing the animals individually in cages with a running wheel assembly connected to a switch that counted each revolution of the wheel and were recorded daily for 3 weeks. Hayes et al. ${ }^{82}$ showed that the forced exercise group had smaller infarct size compared to the voluntary group. The level of stress was significantly higher in the forced group compared to the voluntary group, as indicated by the serum corticosterone levels. The group also showed that the expression of heat shock protein-27 (HSP-27) and HSP-70 was significantly higher in the forced exercise group. The group concluded that the better induced neuroprotection with forced exercise may be attributed to the upregulation of stress induced HSP-27 and -70. They showed that forced exercise with a stressful component is neuroprotective. The group showed the benefits of combination of physical exercise in conjunction with stress, where strenuous exercise is the key factor which provides the stress element. So, the forced exercise regimen may have provided better outcomes because it was more strenuous..$^{82}$ Later in 2011, Kinni et al. ${ }^{83}$ used the same animal models to investigate the differential effects of forced versus voluntary pre-ischemic exercise on cerebral metabolism. They showed that forced exercise induced a significant increase in cerebral glycolysis indicated by the increase in expression of GLUT-1, GLUT-3, PFK, and HIF-1a, and increased AMPK activity, compared to voluntary exercise. The findings suggested that the difference in cerebral metabolism may also be an additional reason behind the better neuroprotection induced by forced exercise. ${ }^{83}$

\section{Heat shock proteins}

Several studies showed that HSPs play a crucial role in mediating the beneficial effects of preconditioning exercise on stroke outcomes. Lin et al..$^{84}$ showed that exercise preconditioning increased the number of HSP-20 containing neurons and astrocytes. This was associated with reduced brain infarcts after stroke, reduced neuronal and glial apoptosis and reduced neurological deficits. Intracerebral injection of small interfering RNA that reduces the neuronal and glial expression of HSP-20 (pSUPER) significantly reversed the exercise-induced benefits. ${ }^{84}$ Liebelt et al. ${ }^{85}$ subjected rats to 30 minutes/day running on treadmill for either 1, 2, or 3 weeks before stroke aiming to determine the least effective exercise period that can induce improvements in stroke outcomes. They showed that only the 3 weeks group showed significant reduction in neuronal apoptosis and brain infarction. However, the group induced stroke by intraluminal suture occlusion. They found that preconditioning exercise for 3 weeks caused a significant increase in the expression of HSP-70 and reduction in the expression of Bax and apoptosis inducing factor (AIF). ${ }^{85}$

In 2019, Wang et al. ${ }^{86}$ showed that preconditioning treadmill training for 3 weeks before stroke significantly reduced infarct size, brain edema, and neurological deficits. This was attributed to the exercise-induced increase in the number of old and newly formed HSP-72 containing neurons. ${ }^{86}$

\section{ERK signaling}

Guo et al. ${ }^{46,48}$ and Chaudhry et al. ${ }^{47}$ showed that preconditioning exercise for 3 weeks led to activation extracellular signalregulated kinase 1/2 (ERK1/2) which let to reduction in poststroke expression of MMP9. This was associated with reduction in neuronal apoptosis and BBB disruption after stroke. ${ }^{46-48}$ In 2010, Liebelt et al. ${ }^{85}$ showed preconditioning exercise for 3 weeks significantly increased the expression of $p E R K 1 / 2$. This was associated with reduced neuronal apoptosis and improved stroke outcomes..$^{85}$ Moreover, Wang et al. ${ }^{87}$ showed that treadmill training for 3 weeks prior to stroke significantly reduced infarct size and improved neurological outcomes due to increased expression of excitatory amino acid transporter-2 (EAAT-2) and decreased overexpression of ERK1/2. The same group also showed that preconditioning treadmill training increased the activity of superoxide dismutase and decreased the concentration of malondialdehyde after stroke. This was associated with reduction in infarct size and neurological deficits. ${ }^{88}$

\section{Conclusions}

Clinical observational studies showed that regular physical exercise reduces the risk of stroke, recurrent stroke and improves 


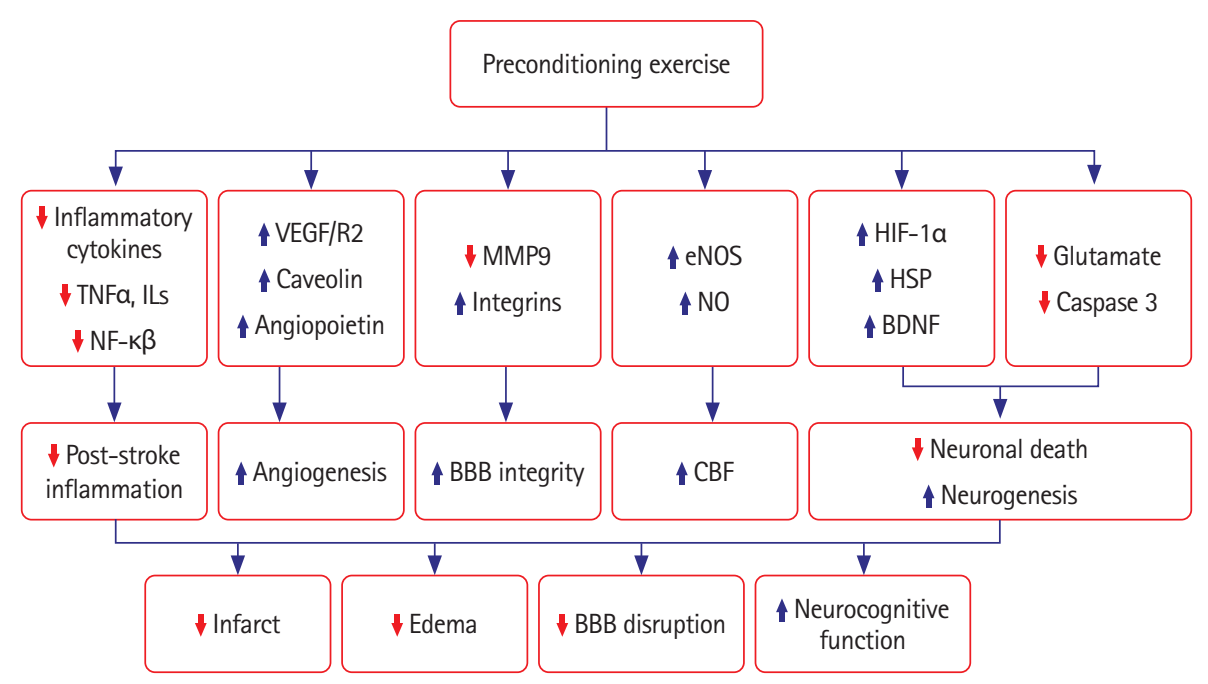

Figure 1. Diagrammatic representation summarizing the different mechanisms employed in the preconditioning exercise-induced neurovascular protection in stroke. Preconditioning exercise may induce neurovascular protection by reducing post-stroke expression and activation of inflammatory cytokines like tumor necrosis factor alpha (TNFa), interleukins (ILs), and nuclear factor kappa B (NF-KB), which in turn reduces post-stroke inflammation; ${ }^{44-53}$ increasing the expression of vascular endothelial growth factor (VEGF), VEGF receptors, caveolin, and angiopoietin in the brain, which in turn may increase angiogenesis and neovascularization; ${ }^{56-58}$ reducing post-stroke expression and activation of matrix metalloproteases (MMPs) and increasing the expression of integrins proteins which may reduce blood-brain barrier (BBB) disruption; ${ }^{46-48,54,55}$ increasing endothelial nitric oxide synthase (eNOS) activation and nitric oxide (NO) production which may increase post-stroke cerebral blood flow (CBF) ${ }_{i}^{62-64}$ increasing expression and activation of hypoxia-inducible factor 1 alpha (HIF-1a), heat shock proteins (HSPs), brain derived neurotrophic factor (BDNF); and inhibition of glutamate and caspase activities which may increase neurogenesis and reduce neuronal death through ${ }^{68-86}$ Collectively, these mechanism may lead to reduction in brain infarction and edema, reduction in BBB disruption and improvement in neurological and functional outcomes.

outcomes and recovery after stroke. ${ }^{17-38}$ Clinical studies have classified leisure-time physical exercise into three categories as low, moderate, or high intensity. Physical exercise sufficient to break a sweat or noticeably raise the heart rate once a week was described as low intensity. Two to three times a week was described as moderate intensity, and four or more times a week was described as high intensity. ${ }^{18,26,89}$ Results from clinical studies showed that a dose of three to five times a week of moderate to high intensity physical exercise can reduce stroke risk and severity, and improve the outcomes. ${ }^{17-38}$ However, the underlying mechanisms through which pre-stroke exercise can improve stroke outcomes are not clear. In this review, we aimed to uncover the underlying mechanisms through which prestroke exercise induces post-stroke neurovascular protection and improves outcomes.

Preclinical studies showed that preconditioning exercise reduces the neurovascular injury after stroke (Table 3) ${ }^{39-88}$ In correlation with the clinical findings, preclinical animal studies employed a dosage regimen of moderate to high intensity exercise three to five times a week. In most studies, moderate intensity referred to running at speed of 15 to $25 \mathrm{~m} / \mathrm{min}$, and high intensity referred to running at speed $>25 \mathrm{~m} / \mathrm{min}^{39-88}$

Preconditioning exercise was shown to reduce brain infarction, brain edema, BBB disruption, and improve the neurological and functional outcomes (Figure 1). The studies showed that exercise induces this neurovascular protection through different intermeshing mechanisms (Figure 1). These mechanisms may involve but not limited to: (1) reducing the poststroke inflammation by reducing the expression and activity of inflammatory cytokines like TNFa, TLRs, and NF-KB after stroke; $^{44-53}(2)$ increasing angiogenesis and neovascularization through increasing the expression of VEGF and VEGF receptors, caveolin, and angiopoietin in the brain; ${ }^{56-58}$ (3) increasing the BBB integrity and reducing disruption through reducing the post-stroke expression of MMPs and increasing the expression of integrins proteins; ${ }^{46-48,54,55}$ (4) increasing post-stroke CBF by increasing eNOS activation and NO production, ${ }^{62-64}$ and (5) increasing neurogenesis and reducing neuronal apoptosis through activation of HIF-1a, HSPs, BDNF, and inhibition of glutamate and caspase activities. ${ }^{68-86}$

It is obvious that the preconditioning exercise-induced protection is due to multiple intermeshing mechanisms and pathways. The interplay between these different mechanisms and molecules in the signaling pathways can be the main cause of the ultimate neurovascular protection. As shown above, exercise increased HIF-1a in the brain which caused reduction in neuronal death, infarction, and neurological deficits. ${ }^{76-83}$ However, HIF-1a may be mediating these positive effects through downstream molecules. HIF-1a may increase the expression and activation of AMPK, GLUTs and may enhance the glycolysis 
enzymes. ${ }^{79-82}$ All these actions may lead to enhanced cerebral metabolism. In addition, HIF-1a can increase the expression of VEGF ${ }^{77,78}$ which may lead to enhanced angiogenesis. ${ }^{56-58}$ Moreover, VEGF can enhance the expression and activation of eNOS, which can lead to enhanced CBF. ${ }^{62,64} \mathrm{HSP}$ s can inhibit the major inflammatory cytokines, mainly NF-KB, which in turn may inhibit the downstream TNFa, IL-1 $\beta$, and IL-6. ${ }^{90,91}$ Inhibition of these cytokines will consequently inhibit the activation of MMP9. Collectively, these actions will inhibit cerebral inflammation, cell death, and BBB disruption. ${ }^{46-48,84-86}$ Inhibition of glutamate-induced excitotoxicity by exercise, may lead to reduction in neuronal apoptosis and cell death. ${ }^{68-76}$ This may be due to reduced calcium ion intracellular influx, increased $\mathrm{Bc} 2$, and reduced Bax leading to reduction in caspases activity, mainly caspase $3{ }^{73-76}$ Exercise also increased BDNF expression in the brain and induced enhanced neurogenesis and neuroplasticity. $^{59-61}$

\section{The concept of exercise mimetics and future thoughts}

Preclinical studies have uncovered many underlying mechanisms employed in the exercise-induced neuroprotection. This is paramount in developing novel therapeutic approaches through the development of exercise pharmacological and non-pharmacological mimetics to combat stroke. For example, (1) RIC shares some mechanistic approaches with exercise like inducing eNOS activation and improving CBF. ${ }^{4}$ (2) The use of metformin was shown to induce the activation of $\mathrm{AMPK}_{1}^{92}$ the principal upstream activator of eNOS. ${ }^{64}$ (3) The use of VEGF mimetics and VEGF receptor agonists to promote cerebral angiogenesis. (4) The use of MMPs inhibitors to reduce post-stroke vascular injury, cerebral hemorrhage, and BBB disruption. All these are thoughts of developing novel exercise mimetics that can be employed in reducing the stroke injury and creating new hopes and therapeutic avenues in stroke management.

\section{Limitations and gaps}

Despite the huge number of preclinical studies conducted to study the impact of exercise on stroke, there are still several limitations and gaps to be filled in this field. Most if not all of the animal studies used: (1) severely intense continuous training exercise models rather than intermittent or interval training which is more relevant to human; (2) intraluminal suture occlusion stroke model which does not have high clinical relevance compared for example to the embolic stroke model; and (3) they all studied the impact of long-term preconditioning exercise without paying much attention to the impact of the short-term exercise. Only one study published recently by Hafez et al. ${ }^{64}$ showed that short-term exercise improved stroke outcome in a clinically relevant thromboembolic stroke model. This goes along with the findings from clinical studies showing that physical exercise the week prior to stroke can reduce the risk and improve the outcomes, ${ }_{1}^{24,35}$ and finally, (4) the use of only young male animals without studying the effects in female or aged animals. These are all gaps and considerations for future studies in the field of exercise-induced neuroprotection.

\section{Disclosure}

The authors have no financial conflicts of interest.

\section{References}

1. Powers WJ, Rabinstein AA, Ackerson T, Adeoye OM, Bambakidis NC, Becker K, et al. Guidelines for the early management of patients with acute ischemic stroke: 2019 update to the 2018 guidelines for the early management of acute ischemic stroke: a guideline for healthcare professionals from the American Heart Association/American Stroke Association. Stroke 2019;50:e344-e418.

2. Powers WJ, Rabinstein AA, Ackerson T, Adeoye OM, Bambakidis NC, Becker K, et al. 2018 Guidelines for the early management of patients with acute ischemic stroke: a guideline for healthcare professionals from the American Heart Association/ American Stroke Association. Stroke 2018;49:e46-e110.

3. Przyklenk K, Whittaker P. Remote ischemic preconditioning: current knowledge, unresolved questions, and future priorities. J Cardiovasc Pharmacol Ther 2011;16:255-259.

4. Hess DC, Blauenfeldt RA, Andersen G, Hougaard KD, Hoda MN, Ding $Y$, et al. Remote ischaemic conditioning-a new paradigm of self-protection in the brain. Nat Rev Neurol 2015;11:698710.

5. Thijssen DHJ, Redington A, George KP, Hopman MTE, Jones $\mathrm{H}$. Association of exercise preconditioning with immediate cardioprotection: a review. JAMA Cardiol 2018;3:169-176.

6. Morris JN, Heady JA, Raffle PA, Roberts CG, Parks JW. Coronary heart-disease and physical activity of work. Lancet 1953;262: 1053-1057.

7. Morris JN, Heady JA, Raffle PA, Roberts CG, Parks JW. Coronary heart-disease and physical activity of work. Lancet 1953;262: 1111-1120.

8. Devlin JT. Effects of exercise on insulin sensitivity in humans. Diabetes Care 1992;15:1690-1693.

9. Henriksson J. Influence of exercise on insulin sensitivity. J Cardiovasc Risk 1995;2:303-309.

10. Hu FB, Sigal RJ, Rich-Edwards JW, Colditz GA, Solomon CG, Willett $W C$, et al. Walking compared with vigorous physical activity and risk of type 2 diabetes in women: a prospective 
study. JAMA 1999;282:1433-1439.

11. Laufs U, Wassmann $S$, Czech $T$, Münzel T, Eisenhauer $M$, Böhm M, et al. Physical inactivity increases oxidative stress, endothelial dysfunction, and atherosclerosis. Arterioscler Thromb Vasc Biol 2005;25:809-814.

12. Wood PD, Stefanick ML, Dreon DM, Frey-Hewitt B, Garay SC, Williams PT, et al. Changes in plasma lipids and lipoproteins in overweight men during weight loss through dieting as compared with exercise. N Engl J Med 1988;319:1173-1179.

13. Boman K, Hellsten G, Bruce A, Hallmans G, Nilsson TK. Endurance physical activity, diet and fibrinolysis. Atherosclerosis 1994;106:65-74.

14. Ernst E. Regular exercise reduces fibrinogen levels: a review of longitudinal studies. Br J Sports Med 1993;27:175-176.

15. Koenig W, Sund M, Döring A, Ernst E. Leisure-time physical activity but not work-related physical activity is associated with decreased plasma viscosity: results from a large population sample. Circulation 1997;95:335-341.

16. Rauramaa $R$, Salonen JT, Seppänen $K$, Salonen $R$, Venäläinen $J M$, Ihanainen $M$, et al. Inhibition of platelet aggregability by moderate-intensity physical exercise: a randomized clinical trial in overweight men. Circulation 1986;74:939-944.

17. Abbott RD, Rodriguez BL, Burchfiel CM, Curb JD. Physical activity in older middle-aged men and reduced risk of stroke: the Honolulu Heart Program. Am J Epidemiol 1994;139:881893.

18. Gillum RF, Mussolino ME, Ingram DD. Physical activity and stroke incidence in women and men: the NHANES I Epidemiologic Follow-up Study. Am J Epidemiol 1996;143:860869.

19. Sacco RL, Gan R, Boden-Albala B, Lin IF, Kargman DE, Hauser $W A$, et al. Leisure-time physical activity and ischemic stroke risk: the Northern Manhattan Stroke Study. Stroke 1998;29: 380-387.

20. Lee $C D$, Folsom $A R$, Blair SN. Physical activity and stroke risk: a meta-analysis. Stroke 2003;34:2475-2481.

21. Willey JZ, Moon YP, Paik MC, Boden-Albala B, Sacco RL, Elkind MS. Physical activity and risk of ischemic stroke in the Northern Manhattan Study. Neurology 2009;73:1774-1779.

22. Lee IM, Paffenbarger RS Jr. Physical activity and stroke incidence: the Harvard Alumni Health Study. Stroke 1998;29: 2049-2054.

23. Armstrong ME, Green J, Reeves GK, Beral V, Cairns BJ; Million Women Study Collaborators. Frequent physical activity may not reduce vascular disease risk as much as moderate activity: large prospective study of women in the United Kingdom. Circulation 2015;131:721-729.

24. Krarup LH, Truelsen $T$, Pedersen $A$, Lerke $H$, Lindahl M, Hansen
$\mathrm{L}$, et al. Level of physical activity in the week preceding an ischemic stroke. Cerebrovasc Dis 2007;24:296-300.

25. Kramer SF, Hung SH, Brodtmann A. The impact of physical activity before and after stroke on stroke risk and recovery: a narrative review. Curr Neurol Neurosci Rep 2019;19:28.

26. Stroud N, Mazwi TM, Case LD, Brown RD Jr, Brott TG, Worrall $\mathrm{BB}$, et al. Prestroke physical activity and early functional status after stroke. J Neurol Neurosurg Psychiatry 2009;80:10191022.

27. Hung SH, Ebaid D, Kramer S, Werden E, Baxter H, Campbell $\mathrm{BC}$, et al. Pre-stroke physical activity and admission stroke severity: a systematic review. Int J Stroke 2021 Feb 23 [Epub]. https://doi.org/10.1177/1747493021995271.

28. Damsbo AG, Mortensen JK, Kraglund KL, Johnsen SP, Andersen $\mathrm{G}$, Blauenfeldt RA. Prestroke physical activity and poststroke cognitive performance. Cerebrovasc Dis 2020;49:632638.

29. Reinholdsson M, Palstam A, Sunnerhagen KS. Prestroke physical activity could influence acute stroke severity (part of PAPSIGOT). Neurology 2018;91:e1461-e1467.

30. Deplanque D, Masse I, Lefebvre $C$, Libersa C, Leys D, Bordet R. Prior TIA, lipid-lowering drug use, and physical activity decrease ischemic stroke severity. Neurology 2006;67:14031410.

31. Deplanque D, Masse I, Libersa C, Leys D, Bordet R. Previous leisure-time physical activity dose dependently decreases ischemic stroke severity. Stroke Res Treat 2012;2012:614925.

32. Ursin MH, Ihle-Hansen $H$, Fure $B$, Tveit $A$, Bergland A. Effects of premorbid physical activity on stroke severity and poststroke functioning. J Rehabil Med 2015;47:612-617.

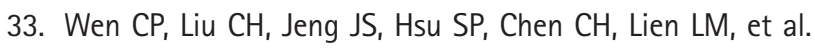
Pre-stroke physical activity is associated with fewer poststroke complications, lower mortality and a better long-term outcome. Eur J Neurol 2017;24:1525-1531.

34. Krarup LH, Truelsen T, Gluud C, Andersen G, Zeng X, Kõrv J, et al. Prestroke physical activity is associated with severity and long-term outcome from first-ever stroke. Neurology 2008;71: 1313-1318.

35. Blauenfeldt RA, Hougaard KD, Mouridsen $K$, Andersen G. High prestroke physical activity is associated with reduced infarct growth in acute ischemic stroke patients treated with intravenous TPA and randomized to remote ischemic perconditioning. Cerebrovasc Dis 2017;44:88-95.

36. Ricciardi AC, López-Cancio $E$, Pérez de la Ossa N, Sobrino $T$, Hernández-Pérez $M$, Gomis $M$, et al. Prestroke physical activity is associated with good functional outcome and arterial recanalization after stroke due to a large vessel occlusion. Cerebrovasc Dis 2014;37:304-311. 
37. López-Cancio E, Ricciardi AC, Sobrino T, Cortés J, de la Ossa $N P$, Millán $M$, et al. Reported prestroke physical activity is associated with vascular endothelial growth factor expression and good outcomes after stroke. J Stroke Cerebrovasc Dis 2017;26:425-430.

38. Bell CL, LaCroix A, Masaki K, Hade EM, Manini T, Mysiw WJ, et al. Prestroke factors associated with poststroke mortality and recovery in older women in the Women's Health Initiative. J Am Geriatr Soc 2013;61:1324-1330.

39. Tahamtan $M$, Allahtavakoli $M$, Abbasnejad M, Roohbakhsh $A$, Taghipour Z, Taghavi M, et al. Exercise preconditioning improves behavioral functions following transient cerebral ischemia induced by 4-vessel occlusion (4-V0) in rats. Arch Iran Med 2013;16:697-704.

40. Shamsaei N, Erfani S, Fereidoni M, Shahbazi A. Neuroprotective effects of exercise on brain edema and neurological movement disorders following the cerebral ischemia and reperfusion in rats. Basic Clin Neurosci 2017;8:77-84.

41. Chen CC, Chang MW, Chang CP, Chan SC, Chang WY, Yang CL, et al. A forced running wheel system with a microcontroller that provides high-intensity exercise training in an animal ischemic stroke model. Braz J Med Biol Res 2014;47:858-868.

42. Jin R, Yang G, Li G. Molecular insights and therapeutic targets for blood-brain barrier disruption in ischemic stroke: critical role of matrix metalloproteinases and tissue-type plasminogen activator. Neurobiol Dis 2010;38:376-385.

43. Lakhan SE, Kirchgessner A, Tepper D, Leonard A. Matrix metalloproteinases and blood-brain barrier disruption in acute ischemic stroke. Front Neurol 2013;4:32.

44. Zwagerman N, Plumlee C, Guthikonda M, Ding Y. Toll-like receptor-4 and cytokine cascade in stroke after exercise. Neurol Res 2010;32:123-126.

45. Zhu L, Ye T, Tang Q, Wang Y, Wu X, Li H, et al. Exercise preconditioning regulates the toll-like receptor $4 /$ nuclear factor- $\kappa B$ signaling pathway and reduces cerebral ischemia/reperfusion inflammatory injury: a study in rats. J Stroke Cerebrovasc Dis 2016;25:2770-2779.

46. Guo M, Cox B, Mahale S, Davis W, Carranza A, Hayes K, et al. Pre-ischemic exercise reduces matrix metalloproteinase- 9 expression and ameliorates blood-brain barrier dysfunction in stroke. Neuroscience 2008;151:340-351.

47. Chaudhry K, Rogers R, Guo M, Lai Q, Goel G, Liebelt B, et al. Matrix metalloproteinase-9 (MMP-9) expression and extracellular signal-regulated kinase 1 and 2 (ERK1/2) activation in exercise-reduced neuronal apoptosis after stroke. Neurosci Lett 2010;474:109-114.

48. Guo M, Lin V, Davis W, Huang T, Carranza A, Sprague S, et al. Preischemic induction of TNF-alpha by physical exercise re- duces blood-brain barrier dysfunction in stroke. J Cereb Blood Flow Metab 2008;28:1422-1430.

49. Curry A, Guo M, Patel R, Liebelt B, Sprague S, Lai $Q$, et al. Exercise pre-conditioning reduces brain inflammation in stroke via tumor necrosis factor-alpha, extracellular signal-regulated kinase 1/2 and matrix metalloproteinase-9 activity. Neurol Res 2010;32:756-762.

50. Ding YH, Young CN, Luan X, Li J, Rafols JA, Clark JC, et al. Exercise preconditioning ameliorates inflammatory injury in ischemic rats during reperfusion. Acta Neuropathol 2005;109: 237-246.

51. Ding YH, Mrizek M, Lai O, Wu Y, Reyes R Jr, Li J, et al. Exercise preconditioning reduces brain damage and inhibits TNFalpha receptor expression after hypoxia/reoxygenation: an in vivo and in vitro study. Curr Neurovasc Res 2006;3:263-271.

52. Li J, Luan X, Clark JC, Rafols JA, Ding Y. Neuroprotection against transient cerebral ischemia by exercise pre-conditioning in rats. Neurol Res 2004;26:404-408.

53. Naderi $S$, Alimohammadi $R$, Hakimizadeh $E$, Roohbakhsh $A$, Shamsizadeh A, Allahtavakoli M. The effect of exercise preconditioning on stroke outcome in ovariectomized mice with permanent middle cerebral artery occlusion. Can J Physiol Pharmacol 2018;96:287-294.

54. Ding YH, Li J, Yao WX, Rafols JA, Clark JC, Ding Y. Exercise preconditioning upregulates cerebral integrins and enhances cerebrovascular integrity in ischemic rats. Acta Neuropathol 2006;112:74-84.

55. He $Z$, Wang $X$, Wu $Y$, Jia J, Hu $Y$, Yang $X$, et al. Treadmill pretraining ameliorates brain edema in ischemic stroke via down-regulation of aquaporin-4: an MRI study in rats. PLoS One 2014;9:e84602.

56. Ding YH, Luan XD, Li J, Rafols JA, Guthinkonda M, Diaz FG, et al. Exercise-induced overexpression of angiogenic factors and reduction of ischemia/reperfusion injury in stroke. Curr Neurovasc Res 2004;1:411-420.

57. Rezaei R, Nasoohi S, Haghparast A, Khodagholi F, Bigdeli MR, Nourshahi M. High intensity exercise preconditioning provides differential protection against brain injury following experimental stroke. Life Sci 2018;207:30-35.

58. Gao Y, Zhao Y, Pan J, Yang L, Huang T, Feng $X$, et al. Treadmill exercise promotes angiogenesis in the ischemic penumbra of rat brains through caveolin-1/VEGF signaling pathways. Brain Res 2014;1585:83-90.

59. Ding $Y$, Li J, Luan $X$, Ding $Y H$, Lai $Q$, Rafols JA, et al. Exercise pre-conditioning reduces brain damage in ischemic rats that may be associated with regional angiogenesis and cellular overexpression of neurotrophin. Neuroscience 2004;124:583591. 
60. Ding YH, Ding Y, Li J, Bessert DA, Rafols JA. Exercise pre-conditioning strengthens brain microvascular integrity in a rat stroke model. Neurol Res 2006;28:184-189.

61. Otsuka S, Sakakima H, Sumizono M, Takada S, Terashi T, Yoshida $Y$. The neuroprotective effects of preconditioning exercise on brain damage and neurotrophic factors after focal brain ischemia in rats. Behav Brain Res 2016;303:9-18.

62. Endres M, Gertz K, Lindauer U, Katchanov J, Schultze J,

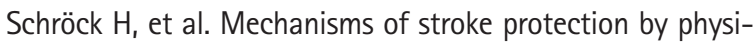
cal activity. Ann Neurol 2003;54:582-590.

63. Gertz K, Priller J, Kronenberg G, Fink KB, Winter B, Schröck H, et al. Physical activity improves long-term stroke outcome via endothelial nitric oxide synthase-dependent augmentation of neovascularization and cerebral blood flow. Circ Res 2006;99:1132-1140.

64. Hafez S, Khan MB, Awad ME, Wagner JD, Hess DC. Shortterm acute exercise preconditioning reduces neurovascular injury after stroke through induced eNOS activation. Trans/ Stroke Res 2020;11:851-860.

65. Zhang $Q$, Zhang $L$, Yang $X$, Wan $Y$, Jia J. The effects of exercise preconditioning on cerebral blood flow change and endothelin-1 expression after cerebral ischemia in rats. J Stroke Cerebrovasc Dis 2014;23:1696-1702.

66. Ankarcrona M, Dypbukt JM, Bonfoco E, Zhivotovsky B, Orrenius S, Lipton SA, et al. Glutamate-induced neuronal death: a succession of necrosis or apoptosis depending on mitochondrial function. Neuron 1995;15:961-973.

67. Moskowitz MA, Lo EH, ladecola C. The science of stroke: mechanisms in search of treatments. Neuron 2010;67:181198.

68. Jia J, Hu YS, Wu Y, Liu G, Yu HX, Zheng QP, et al. Pre-ischemic treadmill training affects glutamate and gamma aminobutyric acid levels in the striatal dialysate of a rat model of cerebral ischemia. Life Sci 2009;84:505-511.

69. Zhang F, Wu Y, Jia J, Hu YS. Pre-ischemic treadmill training induces tolerance to brain ischemia: involvement of glutamate and ERK1/2. Molecules 2010;15:5246-5257.

70. Yang $X, H e$ Z, Zhang O, Wu Y, Hu Y, Wang X, et al. Pre-ischemic treadmill training for prevention of ischemic brain injury via regulation of glutamate and its transporter GLT-1. Int J Mol Sci 2012;13:9447-9459.

71. Wang $X$, Zhang M, Yang SD, Li WB, Ren SQ, Zhang J, et al. Pre-ischemic treadmill training alleviates brain damage via GLT-1-mediated signal pathway after ischemic stroke in rats. Neuroscience 2014;274:393-402.

72. Zhang $F$, Jia J, Wu Y, Hu Y, Wang Y. The effect of treadmill training pre-exercise on glutamate receptor expression in rats after cerebral ischemia. Int J Mol Sci 2010;11:2658-
2669.

73. Shamsaei N, Khaksari M, Erfani S, Rajabi H, Aboutaleb N. Exercise preconditioning exhibits neuroprotective effects on hippocampal CA1 neuronal damage after cerebral ischemia. Neural Regen Res 2015;10:1245-1250.

74. Aboutaleb N, Shamsaei N, Khaksari M, Erfani S, Rajabi H, Nikbakht F. Pre-ischemic exercise reduces apoptosis in hippocampal CA3 cells after cerebral ischemia by modulation of the $\mathrm{Bax} / \mathrm{Bcl}-2$ proteins ratio and prevention of caspase-3 activation. J Physiol Sci 2015;65:435-443.

75. Terashi T, Otsuka S, Takada S, Nakanishi K, Ueda K, Sumizono $M$, et al. Neuroprotective effects of different frequency preconditioning exercise on neuronal apoptosis after focal brain ischemia in rats. Neurol Res 2019;41:510-518.

76. Otsuka S, Sakakima H, Terashi T, Takada S, Nakanishi K, Kikuchi $\mathrm{K}$. Preconditioning exercise reduces brain damage and neuronal apoptosis through enhanced endogenous 14-3-3 $\gamma$ after focal brain ischemia in rats. Brain Struct Funct 2019;224:727738.

77. Bernaudin M, Nedelec AS, Divoux D, MacKenzie ET, Petit E, Schumann-Bard P. Normobaric hypoxia induces tolerance to focal permanent cerebral ischemia in association with an increased expression of hypoxia-inducible factor- 1 and its target genes, erythropoietin and VEGF, in the adult mouse brain. J Cereb Blood Flow Metab 2002;22:393-403.

78. Sharp FR, Bernaudin M. HIF1 and oxygen sensing in the brain. Nat Rev Neurosci 2004;5:437-448.

79. Dornbos D 3rd, Zwagerman N, Guo M, Ding JY, Peng C, Esmail $F$, et al. Preischemic exercise reduces brain damage by ameliorating metabolic disorder in ischemia/reperfusion injury. J Neurosci Res 2013;91:818-827.

80. Dornbos D 3rd, Ding Y. Mechanisms of neuronal damage and neuroprotection underlying ischemia/reperfusion injury after physical exercise. Curr Drug Targets 2012;13:247-262.

81. Wang L, Deng W, Yuan O, Yang H. Exercise preconditioning reduces ischemia reperfusion-induced focal cerebral infarct volume through up-regulating the expression of HIF-1a. Pak J Pharm Sci 2015;28(2 Suppl):791-798.

82. Hayes K, Sprague $S$, Guo M, Davis W, Friedman A, Kumar A, et al. Forced, not voluntary, exercise effectively induces neuroprotection in stroke. Acta Neuropathol 2008;115:289-296.

83. Kinni H, Guo M, Ding JY, Konakondla S, Dornbos D 3rd, Tran $\mathrm{R}$, et al. Cerebral metabolism after forced or voluntary physical exercise. Brain Res 2011;1388:48-55.

84. Lin CM, Chang CK, Chang CP, Hsu YC, Lin MT, Lin JW. Protecting against ischaemic stroke in rats by heat shock protein 20-mediated exercise. Eur J Clin Invest 2015;45:1297-1305.

85. Liebelt B, Papapetrou P, Ali A, Guo M, Ji X, Peng C, et al. Ex- 
ercise preconditioning reduces neuronal apoptosis in stroke by up-regulating heat shock protein-70 (heat shock protein-72) and extracellular-signal-regulated-kinase 1/2. Neuroscience 2010;166:1091-1100.

86. Wang $\mathrm{YL}$, Lin $\mathrm{CH}$, Chen $\mathrm{CC}$, Chang $\mathrm{CP}$, Lin $\mathrm{KC}$, Su FC, et al. Exercise preconditioning attenuates neurological injury by preserving old and newly formed HSP72-containing neurons in focal brain ischemia rats. Int J Med Sci 2019;16:675-685.

87. Wang $X$, Zhang $M$, Feng $R$, Li WB, Ren SQ, Zhang F. Exercise pre-conditioning alleviates brain damage via excitatory amino acid transporter 2 and extracellular signal-regulated kinase 1/2 following ischemic stroke in rats. Mol Med Rep 2015;11: 1523-1527.

88. Feng $R$, Zhang M, Wang $X$, Li WB, Ren SQ, Zhang F. Pre-isch- emic exercise alleviates oxidative damage following ischemic stroke in rats. Exp Ther Med 2014;8:1325-1329.

89. Meschia JF, Brott TG, Brown RD Jr, Crook RJ, Frankel M, Hardy J, et al. The Ischemic Stroke Genetics Study (ISGS) protocol. BMC Neurol 2003;3:4.

90. Kim JY, Yenari MA. The immune modulating properties of the heat shock proteins after brain injury. Anat Cell Biol 2013;46: 1-7.

91. Kim JY, Han Y, Lee JE, Yenari MA. The 70-kDa heat shock protein (Hsp70) as a therapeutic target for stroke. Expert Opin Ther Targets 2018;22:191-199.

92. Zhang CS, Li M, Ma T, Zong Y, Cui J, Feng JW, et al. Metformin activates AMPK through the lysosomal pathway. Cell Metab 2016;24:521-522. 